\title{
ТВОРЧЕСКОЕ МЫШЛЕНИЕ СТУДЕНТОВ ВЫСШЕЙ ШКОЛЫ И ЗНАЧЕНИЕ ЕГО В ПРОЦЕССЕ ОБУЧЕНИЯ
}

\author{
А.С. Старкова \\ Московский гуманитарный университет
}

\begin{abstract}
Аннотация: Встатьерассматриваетсяпонятие «творческоемышление», егоположсительные аспекты, влияющие на процесс обучения студентов высшей школь, а так же - основные принципы развития творческого мышления в трудах зарубежных и отечественных психологов и ученых.

Ключевые слова: прочесс обучения, творческое мылиение, студенты, развитие личности, самостоятельность, самостоятельность мышления, артистизм, творческий потенциал, влияние, развитие
\end{abstract}

\section{CREATIVE THINKING OF HIGHER SCHOOL STUDENTS AND ITS IMPORTANCE IN THE LEARNING PROCESS}

\author{
A.S. Starkova \\ Moscow University for the Humanities
}

\begin{abstract}
The article examines the concept of "creative thinking», its positive aspects that affect the process of teaching students of higher education, as well as the basic principles of the development of creative thinking in the works of foreign and domestic psychologists and scientists.

Keywords: learning process, creative thinking, students, personality development, independence, independence of thinking, artistry, creativity, influence, development

В список необходимых целей и задач продуктивного процесса обучения студентов высшей школы входят десятки самых важных и ответственных критериев, наиболее приоритетными из которых являются развитие активного, гибкого мышления и активизация внутреннего потенциала или творческого мышления.

Творческое мышление является результатом развития активности и гибкости как теоретического, так и практического мышления человека, при котором совершается создание чего-то нового. В теоретическом аспекте творчество проявляется в открытии понятий, гипотез, научных теорий или возможных способах доказательств тех или иных предположений. В практической деятельности творческое мышление способно находить новые выходы решения проблем, усовершенствовать имеющиеся знания и создавать совершенно новые предметы и материалы.

Именно в связи с безграничностью предстающих инструментов творческое мышление привлекало и продолжает привлекать повышенный интерес ученых. При всех известных на данный момент времени научных исследованиях творческое мышление остается одной из самых сложных и по существу не раскрытых проблем.
\end{abstract}


Первые упоминания о творческом мышлении находим у древнегреческого философа Платона, который объясняет творческое мышление как интуицию или озарение и предчувствование (Семёнов, 2001: 92).

Большой вклад в исследование этого понятия внес немецкий психолог М. Вертгеймер, который объявил творческий потенциал как нестандартность, умениевыбиратьлучшиерешения, умениепользоватьсяподсказками,т.е.гибкость мышления. Он выделял также индивидуальные способности творческих людей, среди которых были: критичность, нонконформизм, ассоциальность, «детские» черты характера, желание быть не таким как все, развитое воображение, потребности личности в самореализации и самоактуализации (Вертгеймер, 1987: 115). Помимо этого, аналогично с Платоном, Вертгеймер считал творческое мышление интуицией, озарением или более новым понятием - «инсайтом».

Со стороны психоаналитического исследования выступил Фрейд. По его оценке творческое мышление - это результат скрытого выражения агрессивной и сексуальной энергии, который имеет много общего с фантазиями и сновидениями человека (Фрейд, 1991: 118).

Фрейд, также как Вертгеймер, выделял личностные качества человека, обладающего творческим мышлением: способности к любому виду искусства, воображение, впечатлительность, чувственность, восприимчивость, наблюдательная и гибкая память (Дизраэли, 2000: 120).

Соглашаясь с утверждением Фрейда о влиянии творческого мышления на психическое состояние человека, К. Юнг обращал внимание на развитие личностного роста, при этом считая его базовой энергией либидо. Выделяя, аналогично своим предшественникам, личностные качества, он отмечал внутреннююпотребностьчеловекаввыраженииколлективногоибессознательного (Ходин, 1972: 115).

О творческом мышлении, как о личностном росте говорили также Г. Олпорт и А. Маслоу. Маслоу же помимо этого, выделял творческое мышление как «креативность», в понятие которой вкладывал такие качества, как оригинальность, изобретательность, творческая жилка и самореализация (Маслоу, 2006: 352).

Креативность, как главный аспект творческого мышления, выделял в своих научных трудах и Дж. Гилфорд. В его понимании «креативность» - это формулировка проблемы, продуцирование идеи и актуализации продуктивности, оригинальности и логичности (Ильин, 2011: 78).

Про креативность говорил также Э.Торренс, отмечая ее аналогично с Дж. Гилфордом в способности к решению проблем, где основными критериями решения становятся, как у Платона и Вертгеймера, интуиция, инсайт или озарение (Матюшкин, 2003: 564).

Другие исследователи, объясняя понятие «творческое мышление», отмечали причины замедления развития творческих способностей. Эти доводы высказали: 
Г. Линдсей, К. Халл и Р. Томпсон. По их мнению проблемы с творческим мышлением замедляют личностные качества, приводят к конформизму, страху, зависимости от мнения окружающих, боязни критики и завышению самооценки.

Отечественные ученые аналогично А. Маслоу, Дж. Гилфорду и Э.Торренсу выдели главным критерием творчества - креативность.

А.В. Брушлинский, вводя понятие «социального творчества» выделял, также, как и его предшественники, личные качества творческого человека: индивидуальность, оригинальность и нестандартность (Брушлинский, 1997: 96).

С.Л. Рубинштейн выделял понятие «инсайт», как М. Вертгеймер, Э. Торренс. Творческое мышление он воспринимал как решение определенных проблемных ситуаций и задач, что находит отклик в теориях Дж. Гилфрда и Э. Торренса. Рубинштейн выделял мышление, как дальнейшее действие, т.е. именно алгоритм развития творческого мышления, по его мнению, способен проектировать самые продуктивные пути дальнейшей жизнедеятельности (Рубинштейн, 2009: 35). Одним из первых он также отмечал значение мотивации и определенного эмоционального уровня возбуждения при решении задач.

Я.А. Пономарев выдвигал теорию о бессознательном, в которой выделял два вида опыта: логический и интуитивный. Раскрывал также стадии творческого процесса (схоже с идеями Дж. Гилфорда, Э. Торренса, С.Л. Рубинштейна решение проблемных ситуаций), где первый этап - методы решения, второй попытки решения, на котором включается и интуитивное мышление (о нем же говорилось в теории Платона, М. Вертгеймера, Э. Торренса, С.Л. Рубинштейна) и третий этап - раскрытие замысла (Пономарев, 1976: 296).

Д.Б. Богоявленская изучала творческое мышление с позиции системного подхода, где творчество выступило в качественно- умственной динамичности, т.е. в интеллектуальной инициативе, выход за границы ситуативной заданности, в конечном итоге определяя творческое мышление, как часть общего мыслительного процесса человека, где творчество либо стимулирует творческие способности, либо тормозит (Богоявленская, 1983: 191).

Подводя итоги рассмотрения содержания понятия «творческое мышление» можно сделать выводы, что:

- творческое мышление есть неосознанная внутренняя сила, т.е. интуиция, озарение, предчувствование или в более современной интерпретации «инсайт»;

- люди, обладающие творческим мышлением имеют такие качества личности как: индивидуальность, нестандартность, критичность, нонконформизм, «детские» черты, чувственность, впечатлительность, наблюдательность, потребность в самореализации и самоактуализации, а также - внутреннюю потребность в выражении коллективного и бессознательного;

- к творческим проявлениям личности относят также скорость и гибкость 
мышления, активно развитую фантазию и воображение, отчетливые сновидения, способности к разным видам искусства;

- огромное значение в понятии «творческое мышление» отводится креативности, т.е. способам решения тех или иных задач разными интеллектуальными инструментами;

- среди причин замедления развития творческого мышления выступают такие качества личности, как: страх, конформизм, зависимость от мнения окружающих и боязнь критики;

- в отечественной литературе творческое мышление выделялось как дальнейшее действие и качественно-умственная динамичность, т.е. интеллектуальная инициатива.

Такимобразом,творческоемышлениестудентоввысшейшколыраскрывается как необходимый компонент учебной деятельности, главной задачей которого становится активизация творческого потенциала обучающихся, влекущая за собой повышение общей интеллектуальной деятельности.

\section{СПИСОК ЛИТЕРАТУРЫ}

Богоявленская Д.Б. (1983) Интеллектуальная активность как психологический аспект изучения творчества //Исследование проблем психологии творчества под ред. Я. А. Пономарева. М.: Наука, 315 с.

Брушлинский А.В. (1997) Субъект: мышление, учение, воображение. - МоскваВоронеж, $392 \mathrm{c.}$

Вертгеймер М. (1987) Продуктивное мышление, 275 с.

Дизраэли И. (2000) История гения. Дубна, 207 с.

Маслоу А. (2006) Мотивация и Личность. СПб.: Питер, 352 с.

Матюшкин А.М. (2003) Мышление, обучение, творчество. Москва-Воронеж, 630 с.

Пономарев Я.А. (1976) Психология творчества. М.: Наука, 296 с.

Рубинштейн С.Л. (2009) Основы общей психологии. СПб.: Питер, 713 с.

Семёнов В.В. (2001) Философия души. Сверхчувственная материя и диалектика бессознательного. Пущино. $220 \mathrm{c}$.

Фрейд 3. (1991) Введение в психоанализ. Лекции. М.

Ходин Дж. П. (1972) Современное искусство и современное мышление. Кливленд.

Старкова Анастасия Сергеевна - обучающаяся 3 курса образовательной программы магистратуры по направлению подготовки 44.0.02 Психологопедагогическое образование, кафедра педагогики и психологии высшей школы Московского гуманитарного университета. Научный руководитель - д-р пед. н., профессор В.А. Ситаров. Адрес: 111395, Россия, г. Москва, ул. Юности, д. 5. Тел.: 7 (499) 374 - 74 - 59. Эл. адрес: nastya.starkova2015@yandex.ru 
Starkova Anastasia Sergeevna - 3-year graduate student in the direction of preparation 44.0.02 Psychological and Pedagogical Education, Department of Pedagogy and Psychology of Higher Education scientific supervisor Sitarov V.A., Moscow University for the Humanities. Scientific Adviser - V.A. Sitarov, Doctor of Pedagogy, Professor. Address: 111395, Russia, Moscow, st. Yunosti, 5. Tel .: 7 (499) $374-74$ - 59. address: nastya.starkova2015@yandex.ru

\section{Для цитирования:}

Старкова А.С. Творческое мышление студентов высшей школы и значение его в процессе обучения // Научные труды Московского гуманитарного университета. 2020. №6. C. 67-71. DOI: https://www.doi.org/10.17805/trudy.2020.6.12 